\title{
Soil management and ionic strength on selenate retention in oxidic soils
}

\section{Manejo do solo e força iônica na retenção de selenato em solos oxídicos}

\author{
Anderson Mendes Araujo ${ }^{1}$, Josimar Henrique de Lima Lessa', Liniker André Ferreira ${ }^{1}$ \\ Luiz Roberto Guimarães Guilherme1', Guilherme Lopes ${ }^{1 *}$
}

\author{
${ }^{1}$ Universidade Federal de Lavras/UFLA, Lavras, MG, Brasil \\ "Corresponding author: guilherme.lopes@dcs.ufla.br \\ Received in March 24, 2018 and approved in July 11, 2018
}

\begin{abstract}
Sorption of selenium (Se) on soils may be influenced by factors that are changed though agricultural practices usually performed for crop production, such as soil pH, competing anion and organic matter contents, among others. This study aimed to evaluate the influence of soil management and ionic strength (IS) on Se retention in Brazilian soils, which is important to predict Se availability in both systems, native and cultivated soils. For that, adsorption and desorption reactions of Se were evaluated in 16 soil samples (eight from cultivated soils and eight from native soils), using solutions containing 100 and $500 \mathrm{~g} \mathrm{~L} \mathrm{~L}^{-1}$ Se in the form of sodium selenate and in two IS, 15 and $150 \mathrm{mM}$. Se adsorption varied as a function of IS for most soils, which may indicate that the adsorption mechanism by outer-sphere complex is important for selenate retention in the studied soils, but future studies involving other techniques, such as spectroscopic studies, are needed to more clearly confirm the adsorption mechanism. In general, adsorption varied in relation to soil characteristics, and native soils adsorbed larger Se amounts than the cultivated soils. In terms of desorption, soils which had larger Se adsorbed amounts also presented larger desorbed amounts. Finally, IS and soil management influenced the availability of selenate in the studied soils.
\end{abstract}

Index terms: Adsorption/desorption reactions; brazilian soils; competitive anion; soil cultivation; retention/mobility.

\begin{abstract}
RESUMO
A sorção de selênio (Se) em solos pode ser influenciada por fatores que são alterados pelas práticas agrícolas, as quais são geralmente realizadas para a produção agrícola, tais como o pH do solo, anions competitivos e conteúdo de matéria orgânica, entre outros. Este estudo teve como objetivo avaliar a influência do manejo do solo e da força iônica (FI) na retenção de Se em solos brasileiros, o que é importante para prever a disponibilidade de Se em ambos os sistemas, solos nativos e cultivados. Para isso, as reações de adsorção e dessorção de Se foram avaliadas em 16 amostras de solo (oito de solos cultivados e oito de solos nativos), utilizando soluções contendo 100 e $500 \mu \mathrm{g} \mathrm{L}^{-1}$ sob a forma de selenato de sódio e em duas FI, 15 e 150 mM. A adsorção variou em função da Fl para a maioria dos solos, o que pode indicar que o mecanismo de adsorção por complexo de esfera externa é importante para a retenção de selenato nos solos estudados, mas, estudos futuros envolvendo outras técnicas, como técnicas espectroscópicas, são requeridos para confirmar claramente o mecanismo de adsorção. Em geral, a adsorção variou em relação às características do solo, sendo que os solos nativos adsorveram maiores quantidades de Se que os solos cultivados. Em termos de dessorção, os solos que apresentaram as maiores quantidades adsorvidas de Se também apresentaram as maiores quantidades dessorvidas. Finalmente, a Fl e o manejo do solo influenciaram a disponibilidade de selenato nos solos estudados.
\end{abstract}

Termos para indexação: Reações de adsorção/dessorção; solos brasileiros; ânions competitivos; cultivo do solo; retenção/mobilidade.

\section{INTRODUCTION}

Brazil stands out worldwide as a major agricultural producer, especially in the Cerrado biome. The concern regarding the quality and capacity of products to supply essential nutrients, including selenium (Se), has increased in recent years. Se contents available in the soil can be absorbed and accumulated in the food for humans and animals (Lopes; Ávila; Guilherme, 2017; Wang et al., 2017).
Se is essential for the human body and is directly linked to the elimination of free radicals, reducing several types of cancer (Roman; Jitaru; Barbante, 2014). According to estimates of Hawrylak-Nowak (2013), $15 \%$ of the world population is deficient in Se. Thus, considering the current world population of nearly 7 billion people, it is estimated that approximately 1 billion people are deficient in Se (Warren, 2015). In Brazil, studies have pointed to deficient Se intake by the Brazilian population (Maihara 
et al., 2004), which can be linked to the low Se contents in soils (Gabos; Alleoni; Abreu, 2014a; Matos et al., 2017).

In order to increase Se intake by humans, some countries whose soils are poor in Se, such as Finland, have added this element to fertilizers, increasing its intake by the population, and thus reducing potential risks of deficiency (Alfthan et al., 2015; Winkel et al., 2015). Such action is important to increase Se natural intake by the population, and therefore it is a possible strategy to be used in Brazil. However, to succeed in this practice, studies are required in order to well understand $\mathrm{Se}$ sorption behavior in the soils (Lopes; Ávila; Guilherme; 2017), which will assist in the definition of safe doses to be added to fertilizers, since the limit between the essentiality and the toxicity of this element is quite narrow (Sharma et al., 2017).

Selenium sorption has been studied in a wide range of sorbent materials worldwide (Gabos; Goldberg; Alleoni, 2014b; Lessa et al., 2016; Li et al., 2015; Peak; Sparks, 2002; Söderlund et al., 2016). Most of studies showed that selenite (Se IV) tends to be adsorbed by inner-sphere complex, while Se (VI) forms outer-sphere complex, being this last form (selenate) much more available (Snyder; Um, 2014). Jang, Pak and Kim (2015) reported that Al and Fe oxides play important roles in the ion adsorption on soils, including Se. This fact is of great importance, especially for tropical soils, such as Brazilian soils, where Al and Fe oxides have high contribution to the soil mineralogy (Gomes et al., 2004).

There are few studies on Se adsorption in Brazilian soils (Abreu et al., 2011; Gabos; Goldberg; Alleoni, 2014b; Lessa et al., 2016). Most of these studies involved the addition of high Se doses, and have not evaluated the influence of soil management or cultivation, nor factors such as ionic strength, concentration, and the presence of competing anions that affect Se adsorption and desorption.

This study aimed to evaluate the influence of soil management and ionic strength on Se adsorption and desorption on soils from the Brazilian Cerrado in order to verify the effect of competing anions added to cultivated soils on selenate availability.

\section{MATERIAL AND METHODS}

\section{Soil samples}

Eight different sites were sampled for this study, generating a total of sixteen soil samples. At each site, two samples were collected to a depth of $20 \mathrm{~cm}$, one from a production field and another as close as possible from an adjacent uncropped (native) site. Thus, the difference verified in the Se retention may be due to effects induced by only the soil management, such as changes in $\mathrm{pH}$ and addition of competing anions, as phosphate and sulfate. As described by Lessa et al. (2016) and to characterize these two systems evaluated in this study (cultivated and native soils), it should be noted that most Brazilian Cerrado soils are acidic, have low nutrient availabilities, organic matter contents, and cation exchange capacity, presenting high aluminum contents and P-fixation capacity (Goedert, 1983; Lopes; Guilherme, 2016). Therefore, these soils need to be managed to achieve high crop yields, and soil management practices usually required for these soils are, according to Lopes and Guilherme (2016), based on the concept of soil fertility improvement using limestone, gypsum, and fertilizer application. Thus, the cultivated soils of the present study refer to soils that have been managed for crop production over the time (for approximately 5-15 years), while the native soils of the present study are soils of the Cerrado biome that were not under agricultural management. All samples were collected in the Brazilian Cerrado, comprising the states of Minas Gerais, Mato Grosso, and Goiás (regions of great importance for food production in Brazil). The specific location/state from where each soil sample was collected and the geographic coordinates of the sampling points are shown in Figure 1 and Table 1.

\section{Sample characterization}

Samples were air-dried and sieved ( $2 \mathrm{~mm}$ diameter mesh). Afterwards, they were submitted to chemical and physical characterizations, as well as to Se adsorption and desorption tests. For chemical characterization, analyses were performed as described by Embrapa (1997) to determine available $\mathrm{P}$ and $\mathrm{S}$ contents, aluminum, organic matter, and cation exchange capacity. Total contents of Si, $\mathrm{Al}, \mathrm{Fe}$, and $\mathrm{P}$, in the form of oxides, were measured after $\mathrm{H}_{2} \mathrm{SO}_{4}$ digestion, according to Vettori (1969). Crystalline and amorphous $\mathrm{Fe}$ and $\mathrm{Al}$ contents were measured in the clay fraction after extraction by dithionite citratebicarbonate (DCB-Na) and ammonium oxalate, as recommended by Mehra and Jackson (1958) and Schwertmann (1973), respectively. The predominance of charges in the soil was determined by the point of zero salt effect (PZSE) (Keng; Uehara, 1974). The particle size distribution or soil texture (\% of clay and sand) was determined as recommended by Embrapa (1997). The physical and chemical properties of soils are presented in Table 1.

Mineralogical analyses of native soils were also carried out by X-ray diffraction with the X-ray beamline XRD1 at the Brazilian National Synchrotron Light 
Laboratory - LNLS, in Campinas, Brazil. These analyses were performed on samples ground to $<50 \mu \mathrm{m}$, using a scanning interval of 5 to $45^{\circ} 2 \theta$ and $12 \mathrm{keV}$ energy $(0.1033$ $\mathrm{nm})$. To reduce analytical time and expense, mineralogical analyses were done on native but not cultivated soils. The native samples had been collected as close as possible to where the cultivated soils were sampled, and agricultural management was not expected to produce changes in mineralogy, since these changes require a long period of time to occur (Lopes, 2017; Resende et al., 2014).

Considering that the main minerals found in Brazilian soils are kaolinite $(\mathrm{Ka})$, gibbisite $(\mathrm{Gb})$, hematite
(Hm), and goethite (Gt) (Curi; Franzmeier, 1984; Schaefer; Gilkes; Fernandes, 2004), the amounts of these minerals were calculated in the studied soils in order to assist in the Se-adsorption data interpretation. In this context, the contents of $\mathrm{Hm}$ and $\mathrm{Gt}$ were obtained according to Torrent et al. (1983), while the Ka and Gb amounts were assessed following the methodology reported by Resende, Bahia Filho and Braga (1987). It is important to mention that these methodologies have been used for quantifying these main mineral phases found in tropical soils in several other studies (Carducci et al., 2015; Journet; Balkanski; Harrison, 2014; Oliveira et al., 2013; Reatto et al., 2009).
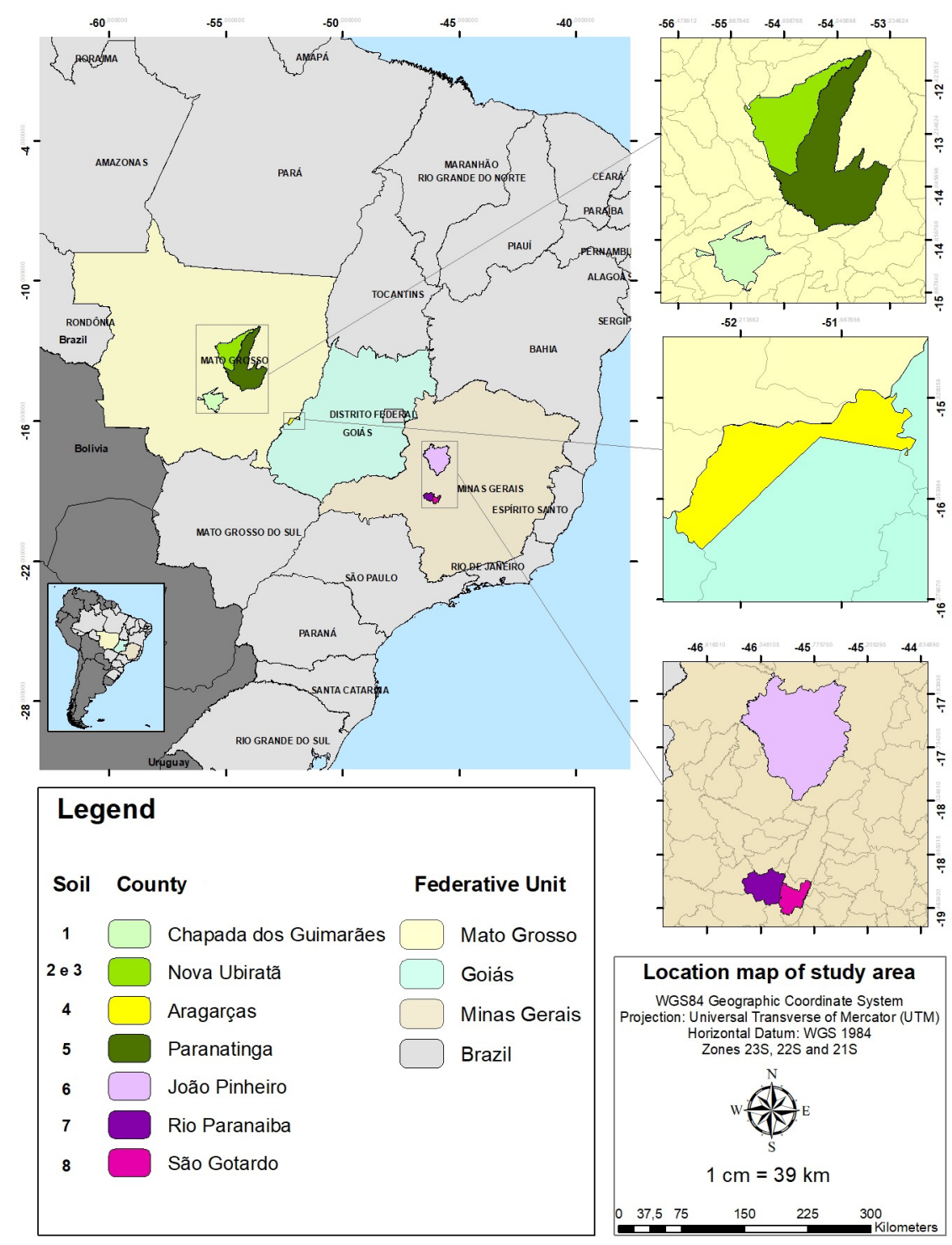

Figure 1: Location map of study areas (states and counties). 


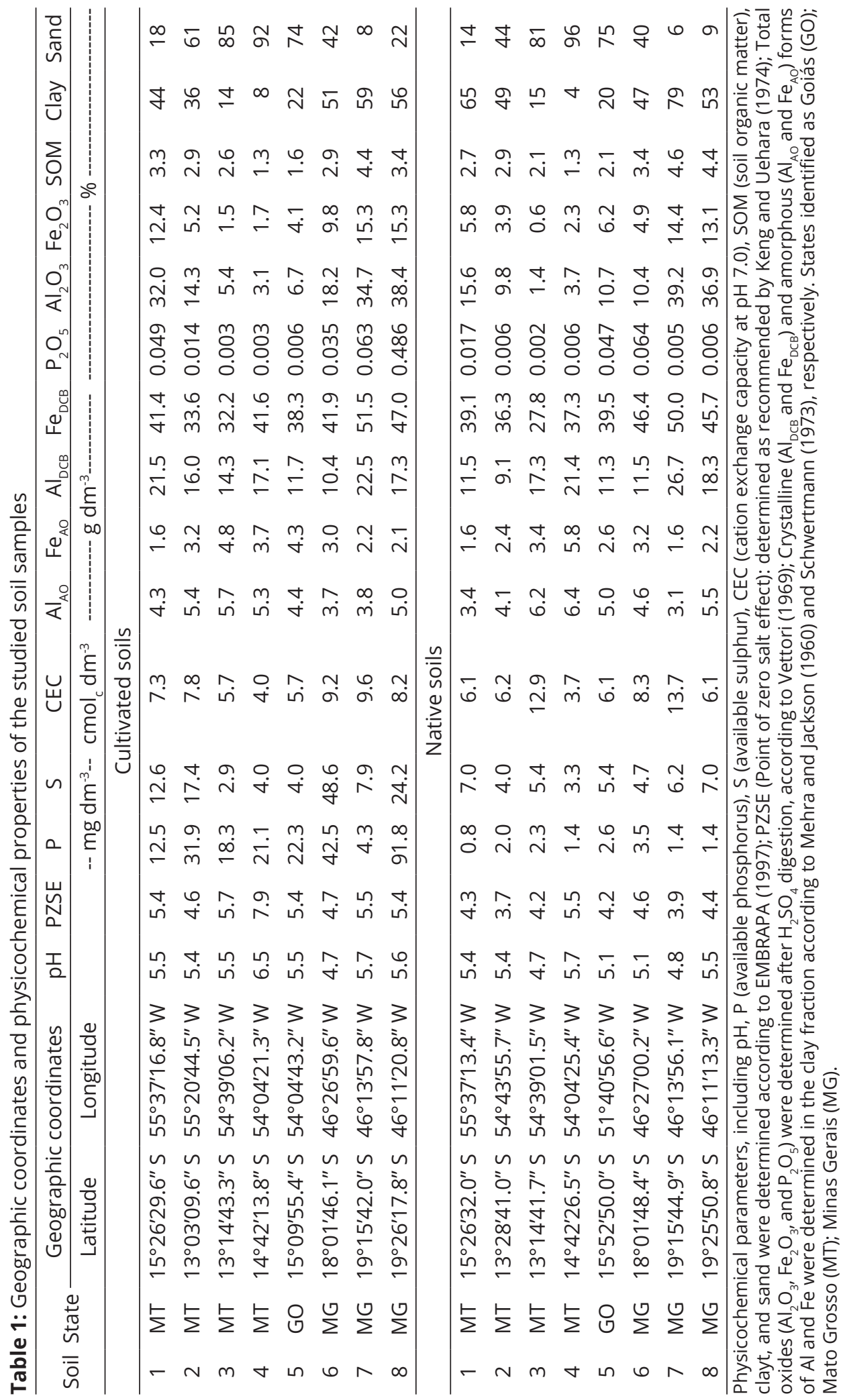




\section{Se adsorption and desorption}

For the Se adsorption experiment, $2.0 \mathrm{~g}$ soil was weighed into triplicate $50-\mathrm{mL}$ centrifuge tubes and then treated with $20 \mathrm{~mL}$ of solutions containing Se at concentrations of 100 and $500 \mu \mathrm{g} \mathrm{L}^{-1}$ (soil:solution ratio of 1:10), which had been prepared with sodium selenate $\left(\mathrm{Na}_{2} \mathrm{SeO}_{4}\right)$, and $\mathrm{NaCl}$ electrolyte solution at two ionic strengths, 15 and $150 \mathrm{mM}$. The lower ionic strength (IS) is comparable to what would characterize the soil solution of weathered soils, while the higher IS of 150 $\mathrm{mM}$ was adopted to obtain a more concentrated solution that would follow a heavy application of gypsum, limestone, or fertilizer, trying to verify the influence of this parameter on Se adsorption. All solutions had been previously adjusted to $\mathrm{pH} 5.5 \pm 0.2$ by adding $\mathrm{HCl}$ or $\mathrm{NaOH}$, both at $0.1 \mathrm{M}$. A pH value of 5.5 was chosen as the recommended $\mathrm{pH}$ for cultivation of the major agricultural crops in Brazil. Adsorption reaction time was 72 hours, with cycles of $12 \mathrm{~h}$ shaking and $12 \mathrm{~h}$ resting. This batch methodology used in the present work has been documented in several studies involving metal adsorption and desorption (Campos et al., 2006), and the reaction time of $72 \mathrm{~h}$ was selected based on previous kinetic studies conducted with Brazilian soils, which showed that $72 \mathrm{~h}$ was sufficient to reach equilibrium in the reaction between the solid and liquid phases (Abreu et al., 2011; Campos et al., 2006). After the reaction period, the suspension of each soil was centrifuged at $2300 \mathrm{rpm}$ for $20 \mathrm{~min}$, and the supernatant was collected to determine Se by Graphite Furnace Atomic Absorption Spectrophotometry (GFAAS).

The amount of Se adsorbed $\left(\mu \mathrm{g} \mathrm{kg}^{-1}\right)$ in the soil was calculated by the following Equation 1:

$S e_{a d s}=(C i-C e) * V / M s$

where $\mathrm{Se}_{\text {ads }}$ is the amount of Se adsorbed in the soil $\left(\mu \mathrm{g} \mathrm{kg}^{-1}\right)$; $\mathrm{C}_{\mathrm{i}}$ is the initial Se concentration in the solution $\left(\mu \mathrm{g} \mathrm{L}^{-1}\right)$; $\mathrm{C}_{\mathrm{e}}$ is the equilibrium $\mathrm{Se}$ concentration after $72 \mathrm{~h}$ reaction with the soil $\left(\mu \mathrm{g} \mathrm{L}^{-1}\right)$; $\mathrm{V}$ is the final volume $(\mathrm{mL})$; and $\mathrm{M}_{\mathrm{S}}$, is the soil mass $(\mathrm{g})$.

Desorption was carried out sequentially after the adsorption step, where in the vials containing the remaining materials from the adsorption study (soil and drops of solution) were added $20 \mathrm{~mL}$ electrolyte solution $(\mathrm{NaCl})$ with the same IS specified previously $(15$ or $150 \mathrm{mM})$. The desorption time remained $72 \mathrm{~h}$, alternating $12 \mathrm{~h}$ shaking and $12 \mathrm{~h}$ rest, with aliquot collection and Se analyses being performed as described for the adsorption test. The amount of Se desorbed was calculated by subtracting the Se concentration in the equilibrium solution from what was previously adsorbed, and the results expressed as a percentage of the previous concentration.

From the adsorption and desorption experiments, effective Se adsorption was calculated (adsorption -desorption) as the amount remaining in the soil after desorption.

Adsorption results were submitted to analysis of variance and means were compared by the Scott-Knott test at 5\% significance $(\mathrm{p}<0.05)$, using the Sisvar software (Ferreira, 2011). The physicochemical properties of the soils were correlated with the adsorbed Se amounts, using the Pearson correlation by the $t$ test, at $5 \%$ significance. Correlations were carried out with the aid of the Sigma Plot $^{\circledR}$ v.12 software.

\section{RESULTS AND DISCUSSION}

\section{Characterization of the studied soils}

Table 1 shows the physicochemical properties of the studied soils. As observed in this table, soil characteristics varied among the studied soil samples. Therefore, comparing cultivated soils with the native ones, there are differences, especially for $\mathrm{pH}$ values and available contents of nutrients, such as $\mathrm{P}$ and $\mathrm{S}$, which were lower for native soils due to long-term agricultural practices applied to the cultivated soils.

X-ray diffractograms of the soils are shown in Figure 2. The identified minerals were: kaolinite (Ka), quartz $(\mathrm{Qz})$, gibbsite $(\mathrm{Gb})$, goethite $(\mathrm{Gt})$, hematite $(\mathrm{Hm})$, anatase $(\mathrm{An})$, magnetite $(\mathrm{Mt})$, cristobalite $(\mathrm{Cr})$, and diaspore (Dp), the first five of which were greatest in frequency and intensity. The presence of these minerals reflects a high intensity of weathering, which would be expected for tropical soils. Figure 2 indicates that soils seven and eight were more strongly weathered than the other soils studied, since there was a larger number of Fe and $\mathrm{Al}$ oxide peaks, and a smaller number and intensity of Ka and Qz peaks.

Tropical soils are predominantly formed by $1: 1$ clays and $\mathrm{Fe}$ and $\mathrm{Al}$ oxides, such as $\mathrm{Ct}, \mathrm{Gb}, \mathrm{Gt}, \mathrm{He}$, and $\mathrm{Mt}$ (Curi; Franzmeier, 1984). This fact is important for anions adsorption, such as selenate, since oxides have high point of zero charge (8.5-9.5), and thus they present positive charges in $\mathrm{pH}$ values found in soils, and have large surface area for ligand exchange reactions (Wang; Chen, 2003). 

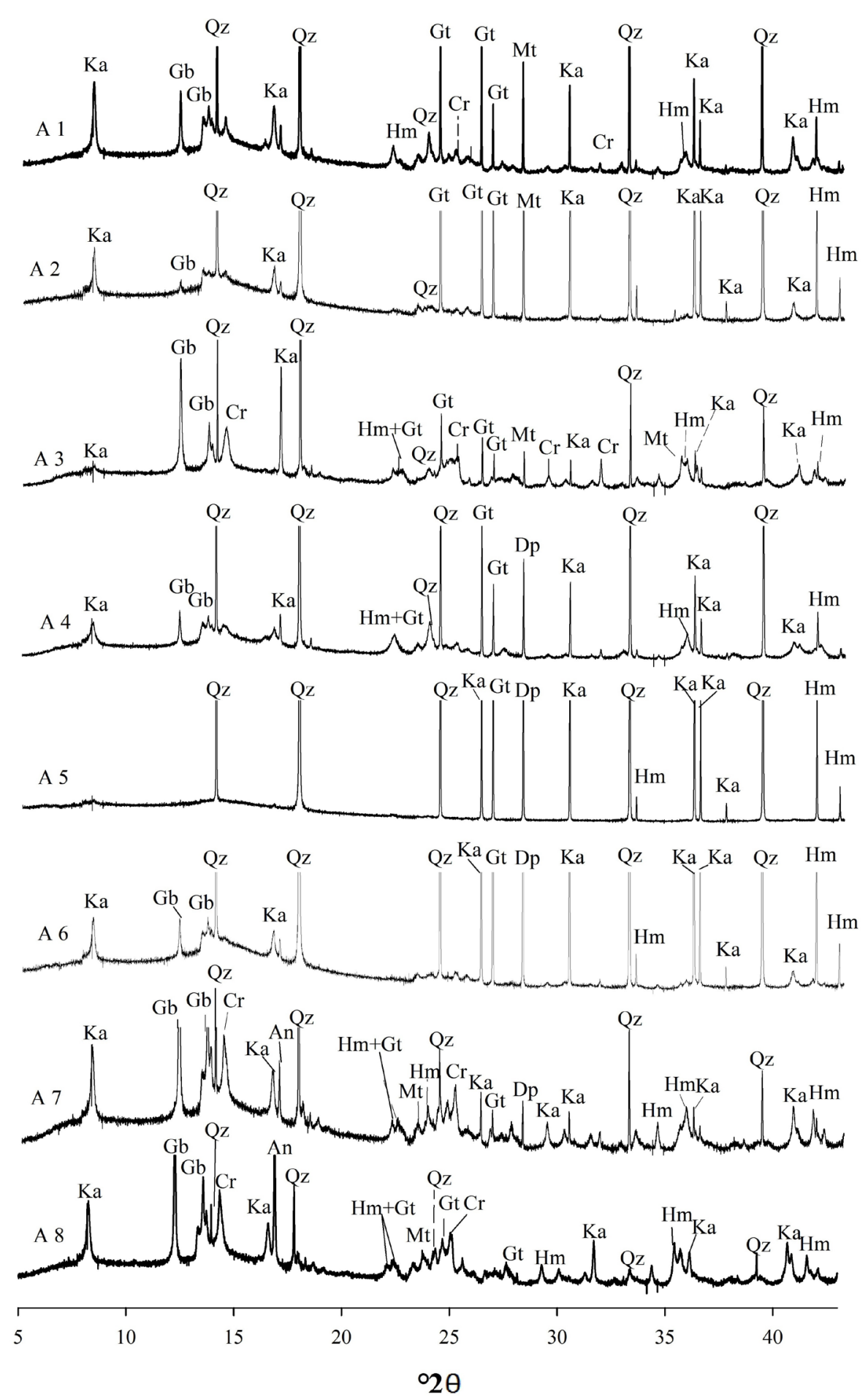

Figure 2: X-ray diffractograms of the native soils. kaolinite (Ka), quartz (Qz), gibbsite (Gb), goethite (Gt), hematite $(\mathrm{Hm})$, anatase $(\mathrm{An})$, magnetite $(\mathrm{Mt})$, cristobalite $(\mathrm{Cr})$, and diaspore. 
Table 2 shows the percentages of $\mathrm{Ka}, \mathrm{Gb}, \mathrm{Gt}$, and $\mathrm{Hm}$ found for the native soils. As it can be seen, the Ka, $\mathrm{Gb}$, Gt, and $\mathrm{Hm}$ percentages varied among the studied soil samples, ranging from 2.8 to $18.3,0$ to $40.8,2.3$ to 4.8 , and 0 to 1.4 , respectively. These percentages of 1:1 clay (Ka) and $\mathrm{Al}$ and $\mathrm{Fe}$ oxides $(\mathrm{Gb}, \mathrm{Gt}$, and $\mathrm{Hm})$ verified for the studied soils are in agreement with values reported elsewhere for typical Brazilian tropical soils (Curi; Franzmeier, 1984; Ferreira; Fernandes; Curi, 1999; Schaefer; Gilkes; Fernandes, 2004). It is important to mention that the lower percentages of $\mathrm{Ka}, \mathrm{Gt}, \mathrm{Hm}$, and $\mathrm{Gb}$ found for soils 3 and 4 can be related to the fact that these are sandy soils, presenting low clay percentages (Table 1).

Table 2: Percentages of kaolinite (Ka), gibbsite (Gb), goethite (Gt), and hematite $(\mathrm{Hm})$ found for the studied native soils.

\begin{tabular}{|c|c|c|c|c|}
\hline Soils & Kaolinite & Gibbsite & Goethite & Hematite \\
\hline & \multicolumn{4}{|c|}{---------------------- \% ---------------------- } \\
\hline 1 & 14.8 & 11.5 & 3.6 & 0.3 \\
\hline 2 & 16.6 & 3.8 & 2.3 & 1.4 \\
\hline 3 & 2.8 & 0.3 & 2.8 & 0.0 \\
\hline 4 & 9.9 & 0.0 & 3.7 & 0.0 \\
\hline 5 & 18.3 & 4.1 & 2.6 & 1.4 \\
\hline 6 & 8.6 & 8.2 & 3.8 & 0.8 \\
\hline 7 & 11.6 & 40.8 & 4.8 & 0.2 \\
\hline 8 & 8.8 & 39.3 & 4.5 & 0.1 \\
\hline Minimum & 2.8 & 0.0 & 2.3 & 0.0 \\
\hline Mean & 11.4 & 13.5 & 3.5 & 0.5 \\
\hline Maximum & 18.3 & 40.8 & 4.8 & 1.4 \\
\hline
\end{tabular}

Hematite and goethite contents were calculated according to Torrent et al. (1983), while kaolinite and gibbsite were obtained according to Resende, Bahia Filho and Braga (1987).

\section{Selenium (VI) adsorption}

The amounts of adsorbed Se (VI) at the studied doses and IS are shown in Figure 3. Firstly, note that the Se adsorbed amounts varied as a function of clay percentages, among other factors, tending to be retained in greater amounts in soils with higher clay percentages, especially considering native soils. However, comparing Se adsorption found for soils of the native areas 2,6 , and 8 , which have similar clay percentages $(49,47$, and $53 \%$, respectively - Table 1$)$, soil 2 adsorbed higher Se amounts than soils 6 and 8, which adsorbed similar Se quantities (Figure 3B). Although these soils presented similar clay percentages (Table 1), Table 2 shows that soil 2 had lower percentages of Gb and Gt and higher percentages of Ka and Hm compared with soils 6 and 8. This fact indicates that $\mathrm{Ka}$, and to a higher extent $\mathrm{Hm}$, play a relevant role in Se retention (Jang; Pak; Kim 2015). Comparing soils 6 and 8, marked differences are found for the percentages of $\mathrm{Gb}$ and $\mathrm{Hm}$. In this context, besides soil 8 presenting much higher $\mathrm{Gb}$ content, soil 6 has greater $\mathrm{Hm}$ percentage and could adsorb similar Se amounts, as reported in Figure 3. Even though present in low percentages in soils, $\mathrm{Hm}$ plays an important role for Se retention on Brazilian soils. Corroborating with that, Rovira at al. (2008), evaluating the sorption of Se (IV) and Se (VI) on natural goethita and hematite, verified that hematite adsorb much more Se (selenite or selenate) than goethita.

It is observed that, in general, the amounts of adsorbed Se varied as a function of the studied IS, mainly at the dose of $100 \mu \mathrm{g} \mathrm{L}^{-1}$ Se. Considering the effect of IS in each soil, when using the lower Se dose $\left(100 \mu \mathrm{g} \mathrm{kg}^{-1}\right)$, it was observed that only the soils of native areas one, two, and seven presented higher adsorption at ionic strength of 15 $\mathrm{mM}$ (Figure 3). In the other soils where there were statistical differences in Se adsorption at the two IS levels, adsorption was higher at the more concentrated IS $(150 \mathrm{mM})$. It is noteworthy that no statistical differences were observed in comparing adsorption between the two studied IS for soils three, five, and six (native), and eight (cultivated), but their adsorption values were greater at the higher IS (Figure 3).

The higher Se adsorption obtained when using the higher IS can be explained due to the adsorption process that occurred at $\mathrm{pH}$ values close to 5.5 (solutions with $\mathrm{pH}=$ 5.5), mostly above the soil's PZSE (Table 1). Under these conditions, the soil surface would carry a net negative charge. According to Xu (2013), the increase in adsorption of some oxyanions upon increasing IS may be observed when the $\mathrm{pH}$ is above the isoelectric point. The presence of higher amounts of counterions in such situation makes the adsorption surface less negative, and therefore increases the adsorption of anions. According to Hiemstra and Van Riemsdijk (1999), oxyanion adsorption increases with the increase in IS, due to lower repulsive interaction between the negative charges of the colloid surface and the negative charges of the ion, since electrolyte ions form a shield on the charged surface when present at high concentrations.

Another reason which might have contributed to higher Se adsorption with the increase in IS is the depression of the diffuse double layer, provided by the increase of ionic concentration in the solution, which increased Se adsorption for being closer to the adsorption region (Zhou et al., 1996). 


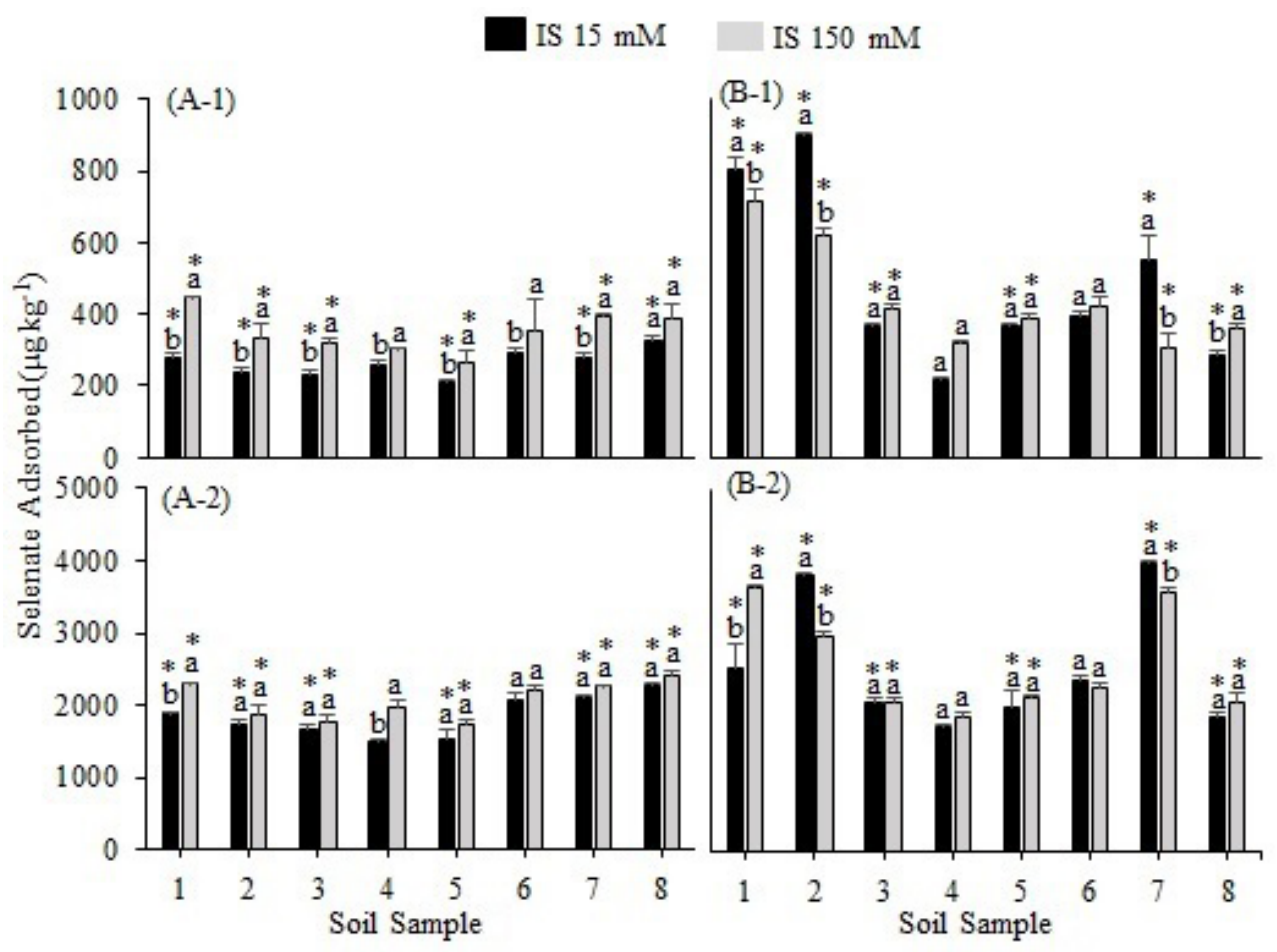

Figure 3: Selenate adsorbed ( $\left.\mu \mathrm{g} \mathrm{kg}^{-1}\right)$ on cultivated (A) and native (B) soils, in the two ionic strength evaluated (15 and $150 \mathrm{mM}$ ). The numbers 1 and 2 after the letters A and B refer to the Se doses of $100 \mu \mathrm{g} \mathrm{L^{-1 }}$ and $500 \mu \mathrm{g} \mathrm{L^{-1 }}$, respectively. The bars that correspond to each quarter of the figure and to each soil sample followed by the same letter do not differ by Scott-Knott test at 95\% probability. The bars with asterisks (*) indicate statistical differences between cultivated (A) and native (B) soils for each studied Se dose (100 $\mu \mathrm{g} \mathrm{L}^{-1}$ (top) or $500 \mathrm{\mu g} \mathrm{L}^{-1}$ (bottom)).

On the other hand, the fact that the native soils one, two, and seven at a dose of $100 \mu \mathrm{g} \mathrm{L}^{-1} \mathrm{Se}$, and soils two

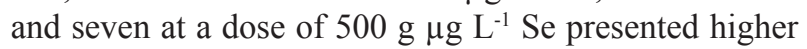
adsorption at the lower ionic strength might have occurred possibly due to some typical characteristics of these soils, such as high clay content and low PZSE values (Table 1). In this context, it is known that soils with low PZSE values tend to have high density of negative charges at the $\mathrm{pH}$ in which adsorption occurred. Moreover, the high clay content contributes to high adsorption contact surface (and with more negative charges due to the low PZSE values). In this context, although part of negative charges can be covered by the cation of the electrolyte solution, the remainder of its negative charges may provide $\mathrm{Se}$ repulsion with the increase of IS from 15 to $150 \mathrm{mM}$, and thus it may reduce Se adsorption at the highest studied IS.

In relation to the type of complex formed between Se and soil colloids, differences in Se adsorption as a function of IS variation were observed mainly at a dose of $100 \mu \mathrm{g} \mathrm{L}^{-1} \mathrm{Se}$, possibly indicating the presence of outersphere complexation or nonspecific adsorption as the main adsorption process considering the whole soil and not for the specific minerals showed in Table 2. Studies have shown that when adsorption is changed by IS variation, adsorption mainly occurs with the formation of outersphere complexes (Duc et al., 2003; Snyder; Um, 2014). For treatments in which the amounts adsorbed did not vary as a function of IS, adsorption may also have occurred due to inner-sphere complexation or specific adsorption, since this process is considered to be active when adsorption is unaffected by IS variations (Hayes; Papelis; Leckie, 1988; Mcbride, 1997; Xu, 2013).

Care must be taken in making inferences on the type of adsorption complex formed based only on the IS factor, since several studies have shown wide dynamics of complexes formed by Se in different types of materials and with changes in factors such as $\mathrm{pH}$ and salt concentration (Abreu et al., 2011; Das; Essilfie-Dughan, 2013; Jang; Pak; Kim, 2015; Sharma et al., 2015). Peak and Sparks (2002) reported that the Se (VI) in hematite only undergoes inner-sphere complexation; however, it forms a mixture of outer- and inner-sphere complexes on goethite surface. 
On the other hand, Rietra, Hiemstra and Van Riemsdijk (2001), when studying the adsorption behavior of selenate and sulfate on goethite, suggested the presence of the outer-sphere complex at $\mathrm{pH}$ above 6 , and a monodentate inner-sphere complex at lower $\mathrm{pH}$. Future studies using X-ray absorption spectroscopy (XAS) analysis, mainly in the EXAFS (extended X-ray absorption fine structure) region of the spectrum, are require to really determine the adsorption mechanism of Se (VI) onto Brazilian soils.

Pearson correlation analysis between the adsorbed amount and the main physical and chemical parameters of the soils are presented in Table 3. First it is noted that a positive correlation was found between Se adsorption and clay content, which is easily understood, considering that clay is the mineral active fraction of the soil. In tropical soils, clay has a fundamental and direct role on anion adsorption, due to the presence of high amounts of 1:1 clays and $\mathrm{Fe}$ and $\mathrm{Al}$ oxides and hydroxides, which are the main sorbents for selenate and other anions (Abreu et al. 2011; Wang; Chen, 2003). The present study also found that Se adsorption was positively correlated with total $\mathrm{Fe}$ and $\mathrm{Al}$ contents (Table 3 ).

Some factors that are influenced by the soil management, such as $\mathrm{pH}, \mathrm{SOM}$, and competing anions
( $\mathrm{S}$ and $\mathrm{P}$ ) presented no correlation with the amount of adsorbed Se when evaluated alone by the Pearson correlation (Table 3). However, the soil management affected the Se adsorption not due to each soil characteristc that was affected but due to an association of attributes that are changed in managed soils (Figure 3 ).

By comparing Se adsorption in native and cultivated soils in each area (Figure 3 ), relationships were identified to the physicochemical properties of each soil, especially their clay content, competing anions, $\mathrm{pH}$, and SOM (Table 3). Soils one, two, and seven presented a similar trend, with higher adsorption in native soils, which could be explained by their fine textures and their low contents of competing ions (P and S), since SOM and $\mathrm{pH}$ were similar between native and cultivated soils (Table 1). Soils three and five also presented significantly higher adsorption in native soil, but with less difference than what was observed for soils one, two, and seven. This finding can be attributed to the low P contents in native soils compared with the cultivated soils (Table 1), whereas parameters such as $\mathrm{pH}$ and clay did not present great variation between native and cultivated soils. Finally, soil management, especially with addition of elements such as $\mathrm{S}$ and $\mathrm{P}$, appears to influence the ability of the soil to adsorb

Table 3: Pearson correlation coefficients between the Se adsorbed amount and the main physicochemical properties of the soil samples.

\begin{tabular}{|c|c|c|c|c|c|c|c|c|}
\hline \multirow{3}{*}{ Soil property } & \multicolumn{4}{|c|}{ Cultivated soils } & \multicolumn{4}{|c|}{ Native soils } \\
\hline & \multicolumn{2}{|c|}{$100 \mu g \mathrm{~L}^{-1} \mathrm{de} \mathrm{Se}$} & \multicolumn{2}{|c|}{$500 \mu \mathrm{g} \mathrm{L}^{-1}$ de Se } & \multicolumn{2}{|c|}{$100 \mu \mathrm{g} \mathrm{L}^{-1}$ de Se } & \multicolumn{2}{|c|}{$500 \mu g \mathrm{~L}^{-1} \mathrm{de} \mathrm{Se}$} \\
\hline & IS 15 & IS 150 & IS 15 & IS 150 & IS 15 & IS 150 & IS 15 & IS 150 \\
\hline Clay & $0.80 * *$ & $0.81 * *$ & $0.87 * *$ & $0.73 * *$ & $0.57 * *$ & $-0.028 n s$ & $0.49 *$ & $0.82 * *$ \\
\hline S & $0.61 * *$ & $0.64 * *$ & $0.57 * \star$ & $0.44 *$ & $0.12 \mathrm{~ns}$ & $-0.36 n s$ & $0.01 \mathrm{~ns}$ & $0.40 \mathrm{~ns}$ \\
\hline$P$ & $0.55^{* *}$ & $0.31 \mathrm{~ns}$ & $0.51 * *$ & $0.37 \mathrm{~ns}$ & $-0.25 n s$ & $0.33 n s$ & $-0.072 n s$ & $-0.46^{*}$ \\
\hline SOM & $0.64^{* *}$ & $0.72^{* *}$ & $0.78^{* *}$ & $0.61 * *$ & $0.152 \mathrm{~ns}$ & $-0.11 \mathrm{~ns}$ & $0.33 n s$ & $0.43 *$ \\
\hline PZSE & $-0.27 n s$ & $-0.53 * *$ & $-0.49 *$ & $-0.14 \mathrm{~ns}$ & $-0.64 * *$ & $-0.47 *$ & $-0.65^{* *}$ & $-0.54 * *$ \\
\hline $\mathrm{Fe}_{\mathrm{AO}}$ & $-0.81 * *$ & $-0.79 * *$ & $-0.69 * *$ & $-0.81 * *$ & $-0.59 * *$ & $-0.12 \mathrm{~ns}$ & $-0.43^{*}$ & $-0.70 * *$ \\
\hline $\mathrm{Al}_{\mathrm{AO}}$ & $-0.40^{*}$ & $-0.47^{\star}$ & $-0.44^{*}$ & $-0.47^{*}$ & -0.74 ** & $-0.07 n s$ & $-0.56 * \star$ & $-0.93 * *$ \\
\hline $\mathrm{Fe}_{D C B}$ & $0.63 * *$ & $0.41 *$ & $0.61 * *$ & $0.71 * *$ & $0.06 \mathrm{~ns}$ & $-0.40 n s$ & $0.45^{*}$ & $0.54 * *$ \\
\hline $\mathrm{Al}_{\mathrm{DCB}}$ & $0.33 \mathrm{~ns}$ & $0.31 \mathrm{~ns}$ & $0.27 \mathrm{~ns}$ & $0.45^{*}$ & $-0.44 *$ & $-0.65 * *$ & $-0.10 \mathrm{~ns}$ & $0.03 \mathrm{~ns}$ \\
\hline $\mathrm{Al}_{2} \mathrm{O}_{3}$ & $0.82 * \star$ & $0.78^{* *}$ & $0.84^{* *}$ & $0.80 * *$ & $0.33 n s$ & $-0.30 n s$ & $0.54 * \star$ & $0.76 * *$ \\
\hline $\mathrm{Fe}_{2} \mathrm{O}_{3}$ & $0.83 * *$ & $0.77 * *$ & $0.85^{* *}$ & $0.81 * *$ & $0.30 \mathrm{~ns}$ & $-0.28 n s$ & $0.50 *$ & $0.70 * *$ \\
\hline $\mathrm{TiO}_{2}$ & 0.71 ** & $0.62^{* *}$ & $0.83^{* *}$ & $0.71 * \star$ & $0.14 \mathrm{~ns}$ & $-0.30 n s$ & $0.47 *$ & $0.57 * *$ \\
\hline $\mathrm{pH}$ & $-0.27 n s$ & $-0.53 * *$ & $-0.42^{\star}$ & $-0.13 n s$ & 0.01 & $0.05 \mathrm{~ns}$ & $-0.42^{\star}$ & $-0.16 n s$ \\
\hline CEC & $0.69 * *$ & $0.60 * \star$ & $0.77^{* *}$ & $0.69 * *$ & $-0.06 n s$ & $-0.42 *$ & $0.38 \mathrm{~ns}$ & $0.20 \mathrm{~ns}$ \\
\hline
\end{tabular}

IS refers to the two ionic strengths tested, 15 and $150 \mathrm{mM}$. ** and * are significant $(\mathrm{P}<0.01$ and $\mathrm{P}<0.05$, respectively); ns: not significant. 
Se, since these anions can partially block adsorption sites, reducing Se retention in cultivated soils. Lower amounts of Se adsorbed on cultivated soils compared with uncultivated soils were also found in other recent study evaluating soil samples from the Mato Grosso, Brazil (Lessa et al., 2016).

\section{Selenium (VI) Desorption}

In general, Se desorbed amounts were related to the clay content and to the sorption capacity of the soils (Figure 4). Thus, desorbed amounts ( $\left.\mu \mathrm{g} \mathrm{kg}^{-1}\right)$ were larger for soils which had previously adsorbed higher Se
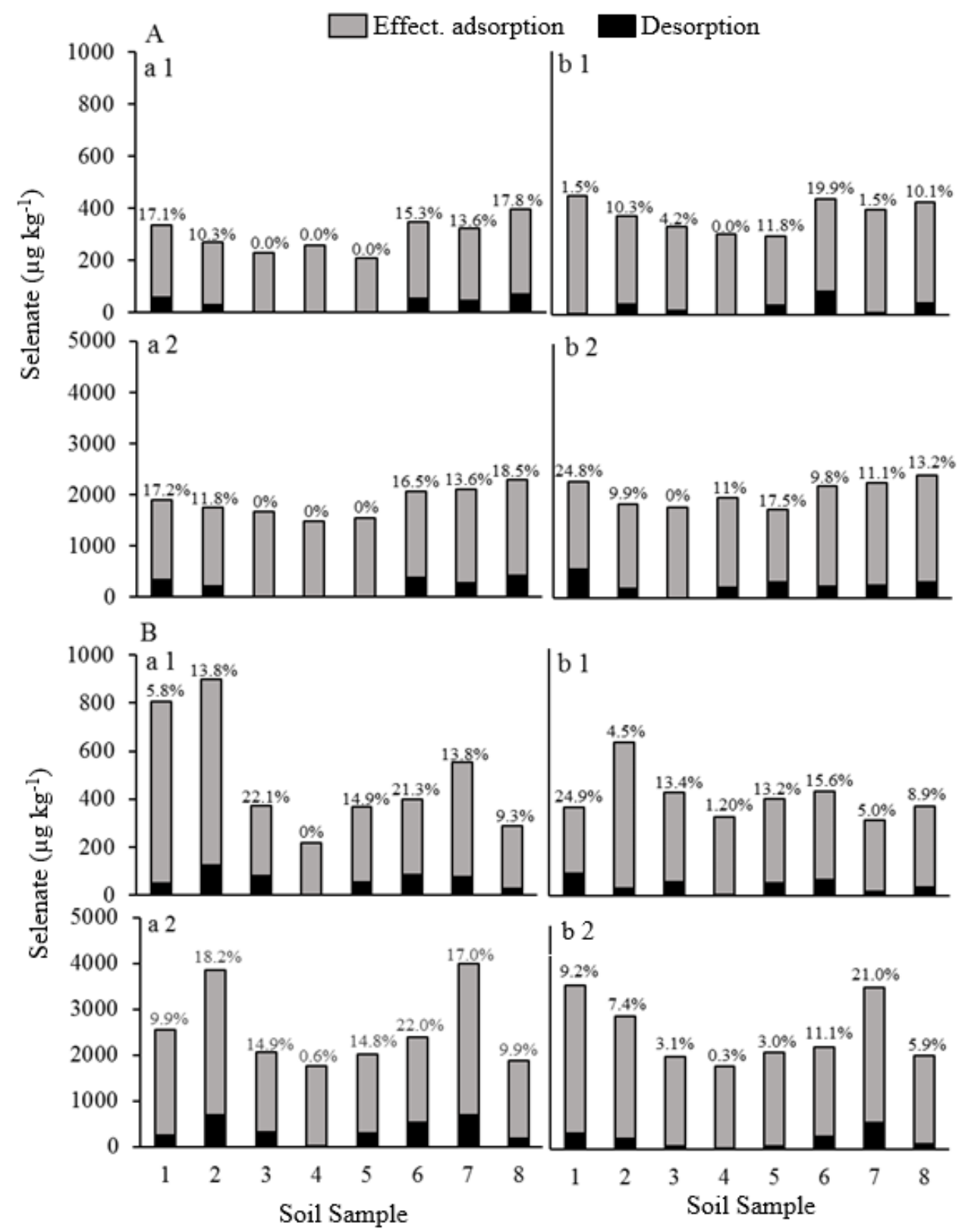

Figure 4: Selenium desorbed ( $\mu \mathrm{g} \mathrm{kg}^{-1}$ ) and selenium effectively adsorbed ( $\mu \mathrm{g} \mathrm{kg}^{-1}$ ) adsorption - desorption) in cultivated (A) and native (B) soils. The lowercase letters (a) and (b) refer to ionic strengths evaluated, 15 and 150 $\mathrm{mM}$, while the numbers 1 and 2 refer to the Se doses of $100 \mu \mathrm{g} \mathrm{L}^{-1}$ and $500 \mathrm{\mu g} \mathrm{L}^{-1}$, respectively. The numbers above the bars indicate Se desorbed percentages in each studied soil. 
amounts. Regarding the clay content, more sandy soils showed low amounts of desorbed Se (some values even below the detection limit of the analytical technique), which can be explained by the low Se amount adsorbed by these soils.

Selenium desorbed percentages are also shown in Figure 4 (numbers above the bars). As can be seen, these percentages are considered low, reaching only up to $25 \%$ as the highest percentage in native soil one when the IS was $150 \mathrm{mM}$. Finally, Figure 4 also shows that there were slightly differences in Se desorption comparing the two studied different IS, presenting no significant differences. Even desorbing larger Se amounts, clayey soils presented a larger amount of Se retained after desorption (effective adsorption), since they had previously adsorbed larger amounts of Se.

\section{CONCLUSIONS}

Selenate adsorption varied among Cerrado soils as a function of their characteristics such as mineralogy, texture, and total content of $\mathrm{Fe}$ and $\mathrm{Al}$ oxides. A strongly positive relationship was observed with clay content, which decreased Se availability. In general, Se adsorption was lower in cultivated soils than in native soils, which strengthen that soil cultivation or management affected the Se sorption and availability, possibly due to the presence of higher amounts of competing anions in cultivated soils than in native soils. Based on the present study evaluating selenate adsorption in different IS values, 15 and 150 $\mathrm{mmol} \mathrm{L}^{-1}$, it is inferred that, in general, the mechanism of outer-sphere complex, or nonspecific adsorption greatly contributes to selenate adsorption in the studied tropical soils. Selenium desorption percentages were low and Se desorption amounts varied as a function of the amount of Se adsorbed to each soil, being larger in soils which had characteristics that contributed to higher adsorption, such as clay content.

\section{ACKNOWLEDGMENTS}

The authors thank the National Council for Scientific and Technological Development $(\mathrm{CNPq}$ - grant \# 455881/2014-6), the Minas Gerais State Research Foundation (FAPEMIG - grant \# APQ-01092-14), and the Coordination for the Improvement of Higher Education Personnel (CAPES) for financial support. Also, we would like to acknowledge the Department of Soil Science for providing the structure used to perform this study and the Brazilian Synchrotron Light Laboratory-LNLS, which provided us the structure for the $\mathrm{x}$-ray diffraction analyses.

\section{REFERENCES}

ABREU, L. B. D. et al. Sorção de selênio nos solos do bioma do cerrado. Revista Brasileira de Ciencia do Solo, 35(6):19952003, 2011.

ALFTHAN, G. et al. Effects of nationwide addition of selenium to fertilizers on foods, and animal and human health in Finland: From deficiency to optimal selenium status of the population. Journal of Trace Elements in Medicine and Biology, 31:142-147, 2015.

CAMPOS, M. L. et al. Força iônica da solução de equilíbrio na adsorção de arsênio em latossolos brasileiros. Pesquisa Agropecuária Brasileira, 41(3):457-460, 2006.

CARDUCCI, C. E. et al. Gypsum effects on the spatial distribution of coffee roots and the pores system in oxidic Brazilian Latosol. Soil Tillage Research, 145:171180, 2015.

CURI, N.; FRANZMEIER, D. Toposequence of Oxisols from the central plateau of Brazil. Soil Science Society of America Journal, 48(2):341-346, 1984.

DAS, S.; HENDRY, M. J.; ESSILFIE-DUGHAN, J. Adsorption of selenate onto ferrihydrite, goethite, and lepidocrocite under neutral pH conditions. Applied Geochemistry, 28:185-193, 2013.

DUC, M. et al. Sorption of selenium anionic species on apatites and iron oxides from aqueous solutions. Journal of Environmental Radioactivity, 70(1):61-72, 2003.

EMPRESA BRASILEIRA DE PESQUISA AGROPECUÁRIA. Manual de métodos de análise do solo. 2 ed. Rio de Janeiro (RJ): EMBRAPA - Solos, 1997. 212p.

FERREIRA, D. F. Sisvar: A computer statistical analysis system. Ciência e Agrotecnologia, 35(6):1039-1042, 2011.

GABOS, M.; ALLEONI, L.; ABREU, C. Background levels of selenium in some selected Brazilian tropical soils. Journal of Geochemical Exploration, 145:35-39, 2014a.

GABOS, M. B.; GOLDBERG, S.; ALLEONI, L. R. F. Modeling selenium (IV and VI) adsorption envelopes in selected tropical soils using the constant capacitance model. Environmental Toxicology and Chemistry, 33(10):21972207, 2014b.

GOEDERT, W. Management of the Cerrado soils of Brazil: A review. European Journal of Soil Science, 34(3):405-428, 1983. 
GOMES, J. B. V. et al. Análise de componentes principais de atributos físicos, químicos e mineralógicos de solos do bioma cerrado. Revista Brasileira de Ciência do Solo, 28(1):137-153, 2004.

HAWRYLAK-NOWAK, B. Comparative effects of selenite and selenate on growth and selenium accumulation in lettuce plants under hydroponic conditions. Plant Growth Regulation, 70(2):149-157, 2013.

HAYES, K. F.; PAPELIS, C.; LECKIE, J. O. Modeling ionic strength effects on anion adsorption at hydrous oxide/solution interfaces. Journal of Colloid and Interface Science, 125(2):717-726, 1988.

HIEMSTRA, T.; VAN RIEMSDIJK, W. Surface structural ion adsorption modeling of competitive binding of oxyanions by metal (hydr) oxides. Journal of Colloid and Interface Science, 210(1):182-193, 1999.

JANG, M.; PAK, S.; KIM, M. J. Comparison of adsorption characteristics of Se (IV) and Se (VI) onto hematite: Effects of reaction time, initial concentration, $\mathrm{pH}$, and ionic strength. Environmental Earth Sciences, 74(2):11691173, 2015.

JOURNET, E.; BALKANSKI, Y.; HARRISON, S. P. A new data set of soil mineralogy for dust-cycle modeling. Atmospheric Chemistry and Physics, 14(8):3801-3816, 2014.

KENG, J. C. W.; UEHARA, G. Chemistry, mineralogy and taxonomy of Oxisols and Ultisols. Soil and Crop Science Society of Florida, 33:119-126, 1974.

LESSA, J. H. et al. Adsorption-desorption reactions of selenium (VI) in tropical cultivated and uncultivated soils under Cerrado biome. Chemosphere, 164:271277, 2016.

$\mathrm{LI}$, Z. et al. Selenite adsorption and desorption in main Chinese soils with their characteristics and physicochemical properties. Journal of Soils and Sediments, 15(5):11501158, 2015.

LOPES, A.; ÁVILA, F. W.; GUILHERME, L. G. Selenium behavior in the soil environment and its implication for human health. Ciência e Agrotecnologia, 41(6):605615, 2017.

LOPES, A. S. Solos Fator e Conceitos - por Diedrich Schroeder - traduzido e adaptado por A. S. Lopes. ed. International Potash Institute (IPI), Suíça, 2017. 245p.

LOPES, A.; GUILHERME, L. G. Chapter one-A career perspective on soil management in the Cerrado Region of Brazil. Advances in Agronomy, 137:1-72, 2016.
MAIHARA, V. et al. Daily dietary selenium intake of selected Brazilian population groups. Journal of Radioanalytical and Nuclear Chemistry, 259(3):465-468, 2004.

MATOS, R. P. et al. Correlation between the natural levels of selenium and soil physicochemical characteristics from the Jequitinhonha Valley (MG), Brazil. Journal of Geochemical Exploration, 172:195-202, 2017.

McBRIDE, M. B. A critique of diffuse double layer models applied to colloid and surface chemistry. Clays and Clay minerals, 45(4):598-608, 1997.

MEHRA, O. P.; JACKSON, M. L. Iron oxide removal from soils and clays by a dithionite-citrate system buffered with sodium bicarbonate. National conference on clays and clays minerals. 7:317-327, 1958.

OLIVEIRA, J. F. et al. Soil discrimination using diffuse reflectance Vis-NIR spectroscopy in a local toposequence. Comptes Rendus Geoscience, 345(11):446-453, 2013.

PEAK, D.; SPARKS, D. Mechanisms of selenate adsorption on iron oxides and hydroxides. Environmental Science \& Technology, 36(7):1460-1466, 2002.

REATTO, A. et al. Development and origin of the microgranular structure in latosols of the Brazilian Central Plateau: Significance of texture, mineralogy, and biological activity. Catena, 76(2):122-134, 2009.

RESENDE, M. et al. Pedologia: Base para distinção de ambientes. 6ed. Lavras: Editora UFLA; 2014. 378p.

RESENDE, M.; BAHIA FILHO, A. F. C.; BRAGA, J. M. Mineralogia da argila de Latossolos estimada por alocação a partir do teor total de óxidos do ataque sulfúrico. Revista Brasileira de Ciência do Solo, 11:17-23, 1987.

RIETRA, R. P.; HIEMSTRA, T.; VAN RIEMSDIJK, W. H. Comparison of selenate and sulfate adsorption on goethite. Journal of colloid and interface science, 240(2):384-390, 2001.

ROMAN, M.; JITARU, P.; BARBANTE, C. Selenium biochemistry and its role for human health. Metallomics, 6(1):25-54, 2014.

ROVIRA, M. et al. Sorption of selenium (IV) and selenium (VI) onto natural iron oxides: Goethite and hematite. Journal of hazardous materials, 150(2):279-284, 2008.

SCHAEFER, C. E. G. R.; GILKES, R. J.; FERNANDES, R. B. A. EDS/ SEM study on microaggregates of Brazilian Latosols, in relation to $\mathrm{P}$ adsorption and clay fraction attributes. Geoderma, 20(1-2):1-33, 2004. 
SCHWERTMANN, U. Use of oxalate for Fe extraction from soils. Canadian Journal of Soil Science, 53(2):244-246, 1973.

SHARMA, V. K. et al. Assessment of toxicity of selenium and cadmium selenium quantum dots: A review. Chemosphere, 188:403-413, 2017.

SHARMA, V. K. et al. Biogeochemistry of selenium. A review. Environmental chemistry letters, 13(1):49-58, 2015.

SNYDER, M. M.; UM, W. Adsorption mechanisms and transport behavior between selenate and selenite on different sorbents. International Journal of Waste Resources, 4(2):1-8, 2014.

SÖDERLUND, M. et al. Sorption and speciation of selenium in boreal forest soil. Journal of Environmental Radioactivity, 164:220-231, 2016.

SYSTAT SOFTWARE I. SigmaPlot for Windows, version 12.0. California: Systat Software Inc, 2014.

TORRENT, J. et al. Quantitative relationships between soil color and hematite content. Soil Science, 136(6):354-358, 1983.

VETTORI, L. Métodos de análise do solo. Rio de Janeiro (RJ): Escritório de Pedologia e Fertilidade de Solos - Ministério da Agricultura, Pecuária e Abastecimento MAPA, 1969. $24 \mathrm{p}$.

WANG, D. et al. Selenate redistribution during aging in different Chinese soils and the dominant influential factors. Chemosphere, 182:284-292, 2017.

WANG, M.; CHEN, H. Forms and distribution of selenium at different depths and among particle size fractions of three Taiwan soils. Chemosphere, 52(3):585-593, 2003.

WARREN, S. G. Can human populations be stabilized?. Earth's Future, 3(2): 82-94, 2015.

WINKEL, L. H. et al. Selenium cycling across soil-plantatmosphere interfaces: A critical review. Nutrients, 7(6):4199-4239, 2015.

$\mathrm{XU}, \mathrm{R}$. K. Interaction between heavy metals and variable charge surfaces. Molecular environmental soil science. In: XU, J.; SPARKS, D. L. Molecular Environmental Soil Science, Dordrecht: Springer; 2013. v.1, p.193-228.

ZHOU, D. et al. Some problems relating to characterizing specific adsorption of heavy-metal ions on surface of oxide: Effect of accompanying anions. Chinese Science Bulletin, 41(17):1483-1487, 1996. 